\title{
The Long-Run Performance of IPOs in Italy: A Comparison of Venture and Non-Venture-Backed Companies
}

\author{
Fabrizio Rossi \\ University of Cassino and Southern Lazio, Cassino, Italy
}

\begin{abstract}
The phenomena associated with the performance of newly listed companies has increased the interest of many researchers who have developed a vast literature on long-term underpricing and underperformance, which together with hot and cold issue markets, represent the three anomalies that have always accompanied with Initial Public Offerings (IPOs). The objective of this work is to investigate the long-run performance of IPOs of venture and non-venture-backed companies. The analysis of a sample of 102 IPOs carried out in Italy in 1998-2005 revealed that both companies (venture-backed and non-venture-backed) showed negative values, thus, confirming the phenomenon of underperformance. During the 36 months following their listing, venture-backed companies seemed to register negative and statistically significant values both with the CARs $\mathrm{VB}_{\mathrm{B}}$ methodology (-93.99\%) and the Buy and Hold Abnormal Returns methodology (BHARs ${ }_{\mathrm{VB}}$-88.37\%). Venture-backed companies, unlike nonventure-backed companies, seem to be able to restrain the losses, measured by both methods, in the first 12 months

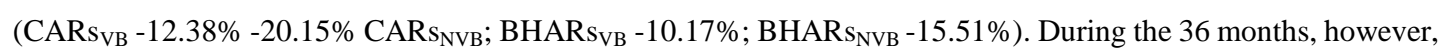
the IPOs showed negative and statistically significant values regardless of whether they were venture or non-venture-backed. The test on the difference between the average abnormal returns of the two methodologies (CAARS and BHAARs) did not produce statistically significant results. The Wealth Relative was calculated and from the results it would appear that the portfolio of venture-backed IPOs does not register "brilliant” performances. The portfolio of 102 IPOs does not seem to beat the "market portfolio". In conclusion, therefore, the phenomenon of underperformance seems to be real in our country and is documented by strongly negative and statistically significant values obtained from the samples of IPOs analyzed.
\end{abstract}

Keywords: portfolio choice, investment decisions, Initial Public Offerings (IPOs), Buy and Hold Abnormal Returns, venture-backed firms, long-run underperformance, Italian stock market, wealth relative

\section{Introduction}

An Initial Public Offering (Offerta Pubblica di Vendita and/or Offerta Pubblica di Sottoscrizione) is the process by which a company is quoted on the stock market to raise venture capital to finance growth or simply to monetize the investment held by the shareholders. While the Offerta Pubblica di Vendita is the sale of securities

Fabrizio Rossi, Ph.D., Adjunct Professor of Economics and Business Organisation, Department of Electrical and Information Engineering, University of Cassino and Southern Lazio.

Correspondence concerning this article should be addressed to Fabrizio Rossi, University of Cassino and Southern Lazio, Via G. Di Biasio 43, Cassino (FR) 03043, Italy. E-mail: f.rossi@unicas.it. 
held by the existing shareholders, the Offerta Pubblica di Sottoscrizione involves the sale of newly issued shares and allows an expansion of the shareholder base in order to create the free float required for listing on the market. Generally, both procedures are used and for this reason they are called OPVS (Offerta Pubblica di Vendita e Sottoscrizione).

In Italy, the increase of IPOs was registered contextually with the expanding size of the Italian stock market in the second half of the 1990s, in particular with the establishment of the various segments, including the Nuovo Mercato, which on the one hand, had the task of allowing high-tech companies to raise "fresh capital" to finance growth, and on the other hand, to create an exit strategy for venture capitalists.

In 1999, the market value of the Offerte Pubbliche di Vendita on the new listings reached a record of 20,155 million euros, while the Offerte Pubbliche di Sottoscrizione peaked in 2000 with 5,156 million euros. The majority of the companies quoted during those years were related to the new economy, and therefore venture capital and private equity have generally had a major role in assisting the new enterprise at the Milan Stock Exchange.

The phenomena associated with the performance of newly listed companies has increased the interest of many researchers, who have developed a vast literature on long-term underpricing and underperformance, which together with hot and cold issue markets, represent the three anomalies that have always accompanied with IPOs.

The objective of this study was to examine long-term underperformance through a sample of 102 IPOs carried out during the period 1998-2005 on the Italian stock market. For this purpose, two methods were used (CARs and BHARs) to see if underperformance is confirmed also in Italy and to what magnitude.

\section{Literature Review on IPOs}

Most of the literature on Initial Public Offerings (IPOs) has mainly focused on two aspects: underpricing and underperformance. The aim of this paper is to examine long-run underperformance. In literature, there is an almost unanimous consensus regarding the long-term negative results for IPOs and this phenomenon was found regardless of the observation period, the number of samples and the reference market of the listed companies. With the exception of Korea (Kim, Krinsky, \& Lee, 1995) and Sweden (Loughran, Ritter, \& Rydqvist, 1994) where it appears that the samples examined register an outperformance compared with the market for values of $91.6 \%$ and $1.2 \%$, respectively, in other countries, the phenomenon of underperformance has been demonstrated in a more or less statistically evident way.

Ritter (1991) on examining a sample of 1,526 firms in the United States during the period 1975-1994, found negative and statistically significant cumulative abnormal returns in the following 36 months (CARs -29.13\%).

Aggarwal, Leal, and Hernandez (1993) during the period 1980-1990, examined a sample of IPOs made up of 62 Brazilian companies and in the long term they registered negative values of almost 50\%. In the same paper, they also analyzed a sample of 28 companies in Chile during the period 1982-1990 and there they also found negative values $(-23.7 \%)$ in the long run.

Levis (1993) surveyed a sample of 483 companies in the UK during the period 1980-1988 and found negative values of $-11.38 \%$ during the following three years. The analysis was conducted considering three different benchmarks and the results confirmed the phenomenon of underperformance in the UK.

Keloharju (1993) examined a sample of 79 Finnish companies during the period 1984-1989 and found 
negative values of $-21.1 \%$ in the following three years.

Leleux (1993) investigated 69 French companies during the period 1985-1991 and in the following three years noted an underperformance of $-10.4 \%$.

Lee, Taylor, and Walter (1994) observed a sample of almost 300 firms during the period 1976-1989 in Australia and found negative abnormal returns of $-46.5 \%$.

Shuster (1996) examined a sample of 88 German firms during the period 1988-1992 and found negative values (-14.13\%).

Rajan and Servaes (1997) illustrated that in the five years following their initial listing, the companies in the sample significantly underperformed the benchmark by values ranging from $-17 \%$ to $-47.1 \%$. Carter, Frederick, and Singh (1998) also found negative and statistically significant values for US firms equal to $19.2 \%$ during the three years following the IPOs, regardless of the comparison benchmark.

Loughran and Ritter (1995), in an extensive study during the period 1970-1990 which included 4,753 companies in the U.S., found negative values of $17 \%$ during the three years following the listing.

The phenomenon of underperformance has been documented also in Italy. Arosio, Giudici, and Paleari (2001) surveyed a sample of 150 IPOs during the period 1985-1999 and found negative abnormal returns of $-11.53 \%$ in the following three years.

Fabrizio and Samà (2001) analyzed 41 IPOs registered in the Italian stock market during the period 1995-1998 and identified cumulative abnormal returns in the following 36 months ranging from $-70.09 \%$ to $-90.74 \%$, depending on the benchmark used. In the period following the 36 months, the cumulative abnormal values for a few benchmarks exceeded $-100 \%$. Equally negative, but lower, were the abnormal returns (-50\%) which they found with the Buy and Hold return methodology. The two authors confirm the existence of long-run underperformance also in Italy, but it actually seems that this anomaly is more pronounced than in other countries.

Many have tried to give an explanation for this “anomaly”. Sefcik and Thompson (1986), Barber and Lyon (1997), Kothari and Warner (1997) and Brav (2000) attributed this phenomenon to the problems of measurement adopted in the long run. For example, Brav and Gompers (1997) analyzed a sample of 934 venture-backed companies during the period 1972-1992 and 3,407 non-venture-backed companies from 1975 to 1992 and found that the anomaly is related to the benchmark used.

Fama and French (1996) and Fama (1998) demonstrated that the long-run performances were very much affected by the methodology used, paving the way for the use of multifactorial models that consider the size and book-to-market in order to provide an empirical explanation of the underperformance.

Kooli and Suret (2001) investigated 445 IPOs in Canada and used both CARs and BHARs methodologies. In their study, a significant underperformance is pointed out in the third and fifth year, ranging from $-15.16 \%$ to $-24.66 \%$ depending on the benchmark.

Gompers and Lerner (2003) examined 3,661 USA IPOs during the period 1935-1972, using both CARs and BHARs, and found differences in the results related to the methodology adopted.

Kooli, L'Her, and Suret (2003) studied a sample of 141 Canadian firms in the period 1986-2000 and noted positive and significant CARs equal to about $15 \%$ for the first year only, while in the third year, returns are negative although not statistically significant. 
Bessler and Kurth (2004) examined the Neuer markt in Germany and found positive long-run performances for both non-venture-backed and venture-backed companies.

Drobetz, Kammermann, and Walchli (2005) analyzed 109 IPOs in Switzerland between 1983 and 2000 and found that the negative abnormal returns appeared to be restrained in the first three years (BHARs -1.69\%) and exceeded $-100 \%$ after eight years.

Jaskiewicz, Gonzalez, Menendez, and Schiereck (2005), on a sample of 153 German companies in the period 1990-2000, found negative returns (BHARs -32.8\%) in the following three years. The same authors examined a sample of 43 companies in Spain during the same period (1990-2000) and found negative values (BHARs -36.7\%).

Bessler and Thies (2007) analyzed a sample of IPOs in Germany during the period 1977-1995 and found negative abnormal returns in the three years following the listing (BHARs -12.7\%).

More recently, Ritter (2008) studied a sample of 6,585 IPOs in the U.S. during the period 1980-2004 and found negative average abnormal returns in the following three years (BHARs $-20.6 \%$ ), which seemed to be more restrained in companies with higher turnovers. Instead, by dividing the sample into two sub-samples that included 2,391 venture-backed companies and 4,450 non-venture-backed companies in the period 1980-2005, he found that non-venture-backed companies registered negative abnormal returns (BHARs -24.7\%) which were higher than those of venture-backed companies (BHARs -13.0\%).

To summarize, although the results found in literature are not homogeneous, they show a substantial underperformance in the long run and some studies point to a worsening of the performance after the second year.

\section{Sample and Survey Methodology}

The analysis sample consists of 102 IPOs of companies that were listed on the Italian stock market during the period 1998-2005. The data were acquired from various sources:

- the prospectuses registered by companies recently listed in the archives of the CONSOB (Commissione Nazionale per le Società e la Borsa);

- the AIFI (Associazione Italiana del Private Equity e Venture Capital) report;

- Bitstat reports (market statistics, various years) of the Italian Stock Exchange.

Subsequently, all information regarding the date of the first day of trading, the selling price, the sector, and the controlling stake held by institutional investors at the time of listing was acquired ${ }^{1}$. Based on the information contained in the prospectuses and the IPOs market report published by AIFI, the sample was divided into two panels (A and B), which included 38 venture-backed companies and 64 non-venture-backed IPOs for a total of 102.

The companies that did not qualify to be defined as venture-backed were automatically included in the panel of non-venture-backed.

The following criteria were adopted for the construction of the final sample:

- The securities of the companies discussed were listed on the Italian Stock Exchange uninterruptedly throughout the survey period and for a period of not less than 12 months from the initial offering;

\footnotetext{
${ }^{1}$ In this study, venture-backed companies are those in which private equity dealers hold more than $2 \%$ of the share capital.
} 
- The time series of prices was acquired from Datastream;

- Only common shares were considered;

- Bank stocks, and more generally financial stocks, and changes in the company from the Mercato Ristretto to the main market were excluded.

For the calculation of performance, the market adjusted return model (or index model) was used for the two reference intervals: the Initial Period Return (IRP), defined as the offering date at the first closing price, and the Aftermarket Period (AP), which includes the 36 months following the IPOs, except for the first day of trading of the Initial Return Period ${ }^{2}$. The Initial Period Return is month 0 , that is, the first day of trading, where each month includes all trading days (in this study, the 21 days after the date of the IPOs was considered), while the Aftermarket Period includes the following 36 months. Therefore, the following procedure was used: 2-22 for the first month, 23-43 for the second and so on (Ritter, 1991). For example, if the first day of IPOs is day 6, according to the market calendar, the first month is composed of days 7-22. For securities that have exited the market prior to 36 months, the Aftermarket Period is cut to the last trading date available.

Long-run performances were estimated using two methods: (1) Cumulative Abnormal Returns (CARs); (2) the Buy and Hold Abnormal Returns (BHARs) methodology as in Ritter (1991), Barber and Lyon (1997), Brav and Gompers (1997), Lyon, Barber, and Tsai (1999), Mitchell and Stafford (2000). The MIBTEL ${ }^{3}$ index was used as a benchmark in both analyses.

\section{First Methodology}

The Abnormal Returns were estimated as follows:

$$
\mathrm{AR}_{\mathrm{it}}=\mathrm{R}_{\mathrm{it}}-\mathrm{R}_{\mathrm{mt}}
$$

where $R_{i t}$ is the return of the security of firm $i$ in the month of event $t$; and $R_{m t}$ is the return of the "portfolio" in the month of event $t$.

The average return of $n$ stocks of the event of month $t$ is obtained as follows:

$$
\mathrm{AR}_{\mathrm{t}}=\frac{1}{\mathrm{n}} \sum_{\mathrm{i}=1}^{\mathrm{n}} \mathrm{AR}_{\mathrm{it}}
$$

The Cumulative Abnormal Returns (CARs) were estimated as follows:

$$
\mathrm{CAR}_{\mathrm{q}, \mathrm{s}}=\sum_{\mathrm{t}=\mathrm{q}}^{\mathrm{s}} \mathrm{AR}_{\mathrm{t}}
$$

where $(q, s)$ represent the months of the IPOs with $q=1$ and $s=12$, 24, and 36 months.

The statistical significance of $A R_{t}$ was estimated as follows:

$$
\mathrm{t}_{\mathrm{AR}_{\mathrm{t}}}=\frac{\mathrm{AR}_{\mathrm{t}}}{\mathrm{SD}_{\mathrm{t}} / \sqrt{\mathrm{n}_{\mathrm{t}}}}
$$

\footnotetext{
2 The exclusion is made in order to avoid that the high returns of the first day of listing influence the calculation of long-term performance.

3 The MIBTEL index is a general basket which includes all the shares listed on the Italian Stock Exchange and has been active since January 3, 1994. It is a value weighted index that is calculated every minute during the continuous trading phase on the basis of prices. It is preferred to use this index, representative of all securities listed on the Italian stock market, because it is larger and closer to the "market portfolio". Currently, it is no longer active, since it has been replaced by the FTSE Italy All-Share.
} 
where $S D_{t}$ is the standard deviation.

Similarly for $C A R_{q, s}$ :

$$
\mathrm{t}_{\mathrm{CAR}_{\mathrm{q}, \mathrm{s}}}=\frac{\mathrm{CAR}_{\mathrm{q}, \mathrm{s}} * \sqrt{\mathrm{n}_{\mathrm{t}}}}{\sqrt{\mathrm{t} * \mathrm{var}+2 *(\mathrm{t}-1) * \mathrm{COV}}}
$$

where $t$ is the month of the event; var is the average variance of $C A R_{q, s}$; $\operatorname{cov}$ is the autocovariance of the first order of the series of $A R_{t}$ of the sample of $n$ firms; and $n_{t}$ is the number of IPOs in the month $t$.

\section{Second Methodology}

The other methodology used in this type of analysis is that of Buy and Hold Returns (BHR), which assumes a maintenance strategy of the "portfolio", rebalanced monthly, throughout the entire observation period of 36 months (Mitchell \& Stafford, 2000).

The returns of the sample firms were calculated as follows:

$$
\mathrm{BHR}_{\mathrm{i}, \mathrm{T}}=\left[\prod_{\mathrm{t}=1}^{\mathrm{T}}\left(1+\mathrm{R}_{\mathrm{i}, \mathrm{t}}\right)\right]-1
$$

where $R_{i, t}$ is the return of the firm $i$ in the month of event $t$; and $T$ is the holding period ( $T=12,24,36$ months for a total of 756 days). For an equally-weighted portfolio of stock the returns are calculated as:

$$
\mathrm{BHR}_{\mathrm{P}, \mathrm{T}}=\frac{1}{\mathrm{n}} \sum_{\mathrm{i}=1}^{\mathrm{n}} \mathrm{BHR}_{\mathrm{i}, \mathrm{T}}
$$

where $B H R_{P, T}$ is the average BHR of the portfolio; $n$ is the number of stocks in the portfolio; and $T$ is the time period for which the BHR is calculated.

The next step consisted in estimating the Buy and Hold Abnormal Returns and the Buy and Hold Average Abnormal Returns as follows:

$$
\begin{gathered}
\operatorname{BHAR}_{\mathrm{i}, \mathrm{T}}=\prod_{\mathrm{t}=1}^{\mathrm{T}}\left(1+\mathrm{R}_{\mathrm{i}, \mathrm{t}}\right)-\prod_{\mathrm{t}=1}^{\mathrm{T}}\left(1+\mathrm{R}_{\text {benchmark,t }}\right) \\
\text { BHAAR }_{\mathrm{i}, \mathrm{T}}=\frac{1}{\mathrm{n}} \sum_{\mathrm{i}=1}^{\mathrm{n}}\left[\prod_{\mathrm{t}=1}^{\mathrm{T}}\left(1+\mathrm{R}_{\mathrm{i}, \mathrm{t}}\right)-\prod_{\mathrm{t}=1}^{\mathrm{T}}\left(1+\mathrm{R}_{\text {benchmark, }}\right)\right]
\end{gathered}
$$

The statistical significance of $B H A R_{i, T}$ was calculated as follows:

$$
\mathrm{t}_{\mathrm{BHAR}_{\mathrm{T}}}=\frac{\mathrm{BHAR}_{\mathrm{T}}}{\sigma\left(\mathrm{BHAR}_{\mathrm{i}, \mathrm{T}}\right) / \sqrt{\mathrm{n}_{\mathrm{t}}}}
$$

Similarly for $B H A A R_{i, T}$ :

$$
\mathrm{t}_{\mathrm{BHAAR}_{\mathrm{T}}}=\frac{\text { BHAAR }_{\mathrm{T}}}{\sigma\left(\mathrm{BHAAR}_{\mathrm{i}, \mathrm{T}}\right) / \sqrt{\mathrm{n}_{\mathrm{t}}}}
$$

Where $\sigma\left(\mathrm{BHAR}_{\mathrm{i}, \mathrm{T}}\right)$ and $\sigma\left(\mathrm{BHAAR}_{\mathrm{i}, \mathrm{T}}\right)$ represent the cross-sectional sample standard deviation of the returns of $n$ firms and $n_{t}$ is the number of IPOs in month $t$.

\section{Wealth Relative}

Like other works (Ritter, 1991; Loughran \& Ritter, 1995), this one also calculated the Wealth Relative (WR), 
both to measure the ratio between the portfolio of IPOs on the "market portfolio" and to calculate the ratio between the performance of the portfolio of venture-backed IPOs and non-venture-backed IPOs.

The following $\left(\mathrm{WR}_{1}\right)$ indicators have been estimated:

$$
\mathrm{WR}_{1_{\mathrm{t}}}=\frac{\left(1+\mathrm{R}_{\text {IPOs }_{\mathrm{t}}}\right)}{\left(1+\mathrm{R}_{\text {benchmark }_{\mathrm{t}}}\right)}
$$

where $\mathrm{R}_{\mathrm{IPO}_{\mathrm{t}}}$ is the buy and hold return of the portfolio at time $t$ and $\mathrm{R}_{\text {benchmark }_{t}}$ is the return of the "market portfolio" during the same period.

Lastly, the second $\left(\mathrm{WR}_{2}\right)$ indicator was estimated, whose terms are the same as the previous one:

$$
\mathrm{WR}_{2_{\mathrm{t}}}=\frac{\left(1+\mathrm{R}_{\mathrm{IPOs}_{\mathrm{VB}_{\mathrm{t}}}}\right)}{\left(1+\mathrm{R}_{\left.\mathrm{IPOs}_{\mathrm{NVB}_{\mathrm{t}}}\right)}\right)}
$$

If an indicator value greater than 1 means that the average return over the three years of the buy-and-hold portfolio has outperformed the benchmark; a value less than 1 indicates that the benchmark has done "better" than the portfolio of IPOs. The same is valid for $\mathrm{WR}_{2}$, except that in this case a value greater than 1 indicates that the portfolio of IPOs $\mathrm{VB}_{\mathrm{VB}}$ showed better performance than the portfolio of IPOs $\mathrm{sVB}_{\mathrm{NV}}$ and vice versa in the presence of a value less than one.

\section{Results and Discussion}

A sample of 102 IPOs has been examined during the period 1998-2005 using both the Cumulative Abnormal Returns (CARs) methodology and the Buy and Hold Abnormal Returns (BHARs) strategy. Thus, 38 venture-backed companies (VB) and 64 non-venture-backed companies (NVB) make up the sample.

Table 1 shows the unadjusted performances of the IPOs in the reference period. The venture-backed companies seem to perform "better" than the non-venture-backed companies in the first 12 months. In the second year, they performed worse than the non-venture-backed companies. The mean and median of the venture-backed companies were negatively higher than the non-venture-backed companies.

Table 2 reveals that both venture-backed and non-venture-backed companies registered negative and statistically significant cumulative abnormal returns (CARs $\mathrm{VB}_{\mathrm{VB}}-93.99 \%$; CARs $_{\mathrm{NVB}}-77.28 \%$ ) in the following 36 months.

The venture-backed companies registered negative, but not statistically significant, cumulative abnormal returns (CARs ${ }_{\mathrm{VB}}-12.38 \%$ ) in the first 12 months, and more restrained than non-venture-backed companies $\left(\mathrm{CARs}_{\mathrm{NVB}}-20.15 \%\right)$. However, at the end of the period, the venture-backed companies registered negative and statistically significant values which were higher than those of non-venture-backed companies (CARs $\mathrm{VB}_{\mathrm{V}}-93.99 \%$; $\left.\mathrm{CARs}_{\mathrm{NVB}}-77.28 \%\right)$.

Table 3 shows the analysis of Cumulative Average Abnormal Returns (CAARs) which was carried out by observing different time windows. The CAARs point out how IPOs concerning both venture-backed and non-venture-backed companies registered negative values immediately after listing. In the first six months both registered negative values, but statistically significant values only for non-venture-backed companies (CAARs $-15.34 \%)$. 
Table 1

The Unadjusted Returns for Both Venture-Backed Firms and Non-Venture-Backed Firms for the 36 Months Following the IPOs

\begin{tabular}{|c|c|c|c|c|}
\hline \multirow{2}{*}{ Month } & \multicolumn{2}{|c|}{ Venture-backed firms (VB) } & \multicolumn{2}{|c|}{ Non-venture-backed firms (NVB) } \\
\hline & Number of firms & Unadjusted return & Number firms & Unadjusted return \\
\hline 1 & 38 & $6.55 \%$ & 64 & $5.95 \%$ \\
\hline 2 & 38 & $5.07 \%$ & 64 & $1.76 \%$ \\
\hline 3 & 38 & $-2.49 \%$ & 64 & $1.53 \%$ \\
\hline 4 & 38 & $8.41 \%$ & 64 & $-0.08 \%$ \\
\hline 5 & 38 & $-0.64 \%$ & 64 & $-0.32 \%$ \\
\hline 6 & 38 & $-4.85 \%$ & 64 & $0.32 \%$ \\
\hline 7 & 38 & $-2.35 \%$ & 64 & $1.60 \%$ \\
\hline 8 & 38 & $0.46 \%$ & 64 & $0.89 \%$ \\
\hline 9 & 38 & $-3.52 \%$ & 64 & $-0.08 \%$ \\
\hline 10 & 38 & $3.00 \%$ & 64 & $-0.96 \%$ \\
\hline 11 & 38 & $3.37 \%$ & 64 & $-2.86 \%$ \\
\hline 12 & 38 & $-1.13 \%$ & 64 & $-3.62 \%$ \\
\hline 13 & 38 & $-0.38 \%$ & 64 & $0.25 \%$ \\
\hline 14 & 38 & $-0.04 \%$ & 64 & $-4.13 \%$ \\
\hline 15 & 38 & $-0.38 \%$ & 64 & $-1.78 \%$ \\
\hline 16 & 38 & $-2.50 \%$ & 64 & $1.73 \%$ \\
\hline 17 & 38 & $-1.04 \%$ & 64 & $-0.68 \%$ \\
\hline 18 & 38 & $-0.90 \%$ & 64 & $-0.02 \%$ \\
\hline 19 & 38 & $-0.63 \%$ & 64 & $-1.27 \%$ \\
\hline 20 & 38 & $-4.14 \%$ & 64 & $-2.27 \%$ \\
\hline 21 & 38 & $-2.77 \%$ & 64 & $-1.90 \%$ \\
\hline 22 & 38 & $-2.14 \%$ & 64 & $-1.66 \%$ \\
\hline 23 & 38 & $-3.12 \%$ & 64 & $-2.34 \%$ \\
\hline 24 & 38 & $-5.10 \%$ & 64 & $-2.58 \%$ \\
\hline 25 & 38 & $-4.44 \%$ & 64 & $0.37 \%$ \\
\hline 26 & 38 & $-1.84 \%$ & 64 & $-1.11 \%$ \\
\hline 27 & 38 & $-7.00 \%$ & 64 & $-3.45 \%$ \\
\hline 28 & 37 & $-1.26 \%$ & 64 & $-0.98 \%$ \\
\hline 29 & 37 & $-0.26 \%$ & 64 & $3.02 \%$ \\
\hline 30 & 37 & $0.98 \%$ & 63 & $0.07 \%$ \\
\hline 31 & 37 & $-4.98 \%$ & 63 & $-2.08 \%$ \\
\hline 32 & 37 & $2.33 \%$ & 63 & $-1.68 \%$ \\
\hline 33 & 37 & $-2.81 \%$ & 63 & $-2.46 \%$ \\
\hline 34 & 37 & $0.27 \%$ & 64 & $-0.07 \%$ \\
\hline 35 & 37 & $-4.54 \%$ & 62 & $1.27 \%$ \\
\hline 36 & 37 & $-0.74 \%$ & 62 & $-0.85 \%$ \\
\hline \multicolumn{5}{|c|}{ Descriptive statistics of the sample } \\
\hline Mean & & $-0.99 \%$ & & $-0.57 \%$ \\
\hline Median & & $-1.09 \%$ & & $-0.77 \%$ \\
\hline SD & & 0.03 & & 0.02 \\
\hline Min & & $-7.00 \%$ & & $-4.13 \%$ \\
\hline Max & & $8.41 \%$ & & $5.95 \%$ \\
\hline
\end{tabular}

Notes. The sample consists of 102 IPOs that occurred between January 1, 1998 and December 31, 2005: 38 Venture-Backed Companies (VB) and 64 Non-Venture-Backed Companies (NVB) make up the sample. The $A R s_{t}$ and $C A R s_{1, t}$ were estimated for the 36 months following the IPOs, excluding the initial return. 
Table 2

The Results of Abnormal Returns (ARs) and Cumulative Abnormal Returns (CARs) for the 36 Months Following the IPOs

\begin{tabular}{|c|c|c|c|c|c|c|c|c|c|c|}
\hline \multirow{2}{*}{ Month } & \multicolumn{5}{|c|}{ IPOs VB } & \multicolumn{5}{|c|}{ IPOs NVB } \\
\hline & Sample size & $\mathrm{AR}_{\mathrm{tVB}}$ & $t$-test & $\mathrm{CAR}_{\mathrm{tVB}}$ & $t$-test & Sample size & $\mathrm{AR}_{\mathrm{tNVB}}$ & $t$-test & $\mathrm{CAR}_{\mathrm{tNVB}}$ & $t$-test \\
\hline 1 & 38 & $-3.86 \%$ & -0.56 & $-3.86 \%$ & -1.24 & 64 & $-4.46 \%$ & -1.23 & $-4.46 \%^{b}$ & -2.56 \\
\hline 2 & 38 & $-1.34 \%$ & -0.16 & $-5.19 \%$ & -1.09 & 64 & $-4.65 \%^{\mathrm{b}}$ & -2.06 & $-9.11 \%^{\mathrm{c}}$ & -3.26 \\
\hline 3 & 38 & $-22.38 \%^{\mathrm{c}}$ & -11.96 & $-27.58 \%^{\mathrm{c}}$ & -4.59 & 64 & $-18.37 \%^{\mathrm{c}}$ & -7.12 & $-27.48 \%^{\mathrm{c}}$ & -7.74 \\
\hline 4 & 38 & $20.02 \%^{\mathrm{c}}$ & 3.00 & $-7.56 \%$ & -1.08 & 64 & $11.53 \%^{\mathrm{c}}$ & 5.08 & $-15.95 \%^{\mathrm{c}}$ & -3.83 \\
\hline 5 & 38 & $-4.73 \%^{\mathrm{a}}$ & -1.92 & $-12.29 \%$ & -1.55 & 64 & $-4.41 \%^{\mathrm{a}}$ & -1.72 & $-20.36 \%^{\mathrm{c}}$ & -4.33 \\
\hline 6 & 38 & $0.49 \%$ & 0.27 & $-11.80 \%$ & -1.35 & 64 & $5.66 \%{ }^{c}$ & 3.60 & $-14.70 \%^{\mathrm{c}}$ & -2.83 \\
\hline 7 & 38 & $-10.61 \%^{\mathrm{c}}$ & -5.57 & $-22.41 \%^{\mathrm{b}}$ & -2.37 & 64 & $-6.66 \%{ }^{c}$ & -4.01 & $-21.36 \%{ }^{\mathrm{c}}$ & -3.79 \\
\hline 8 & 38 & $5.55 \%^{\mathrm{b}}$ & 2.37 & $-16.86 \%$ & -1.67 & 64 & $5.98 \%{ }^{c}$ & 3.66 & $-15.38 \%^{\mathrm{b}}$ & -2.55 \\
\hline 9 & 38 & $13.08 \%^{c}$ & 8.30 & $-3.78 \%$ & -0.35 & 64 & $16.51 \%^{\mathrm{c}}$ & 8.71 & $1.13 \%$ & 0.18 \\
\hline 10 & 38 & $1.08 \%$ & 0.23 & $-2.70 \%$ & -0.24 & 64 & $-2.88 \%^{\mathrm{a}}$ & -1.78 & $-1.75 \%$ & -0.26 \\
\hline 11 & 38 & $-6.30 \%{ }^{\mathrm{b}}$ & -2.49 & $-9.00 \%$ & -0.76 & 64 & $-12.54 \%^{\mathrm{c}}$ & -6.87 & $-14.29 \%^{\mathrm{b}}$ & -2.00 \\
\hline 12 & 38 & $-3.37 \%$ & -1.15 & $-12.38 \%$ & -0.99 & 64 & $-5.86 \%^{\mathrm{c}}$ & -4.22 & $-20.15 \%^{\mathrm{c}}$ & -2.70 \\
\hline 13 & 38 & $-5.27 \% \%^{\mathrm{b}}$ & -2.40 & $-17.65 \%$ & -1.36 & 64 & $-4.65 \%{ }^{\mathrm{c}}$ & -2.78 & $-24.80 \%^{\mathrm{c}}$ & -3.19 \\
\hline 14 & 38 & $4.36 \%^{\mathrm{a}}$ & 1.93 & $-13.29 \%$ & -0.99 & 64 & $0.27 \%$ & 0.19 & $-24.53 \%^{\mathrm{c}}$ & -3.04 \\
\hline 15 & 38 & $-8.97 \%{ }^{\mathrm{c}}$ & -3.68 & $-22.26 \%$ & -1.59 & 64 & $-10.37 \%^{\mathrm{c}}$ & -5.17 & $-34.90 \%{ }^{\mathrm{c}}$ & -4.17 \\
\hline 16 & 38 & $-1.51 \%$ & -0.66 & $-23.77 \%$ & -1.65 & 64 & $2.72 \%$ & 1.01 & $-32.18 \%^{c}$ & -3.72 \\
\hline 17 & 38 & $5.16 \%^{\mathrm{b}}$ & 2.47 & $-18.61 \%$ & -1.25 & 64 & $5.52 \%^{c}$ & 3.83 & $-26.66 \%^{c}$ & -2.99 \\
\hline 18 & 38 & $-2.00 \%$ & -0.96 & $-20.61 \%$ & -1.34 & 64 & $-1.12 \%$ & -0.82 & $-27.78 \%{ }^{\mathrm{c}}$ & -3.02 \\
\hline 19 & 38 & $-1.89 \%$ & -0.84 & $-22.50 \%$ & -1.43 & 64 & $-2.53 \%^{\mathrm{a}}$ & -1.89 & $-30.31 \%^{c}$ & -3.21 \\
\hline 20 & 38 & $3.79 \%^{\mathrm{b}}$ & 2.69 & $-18.72 \%$ & -1.16 & 64 & $5.66 \%{ }^{c}$ & 4.00 & $-24.65 \%^{\mathrm{b}}$ & -2.54 \\
\hline 21 & 38 & $-7.23 \%{ }^{\mathrm{c}}$ & -3.00 & $-25.95 \%$ & -1.57 & 64 & $-6.37 \%^{\mathrm{c}}$ & -5.37 & $-31.02 \%^{c}$ & -3.12 \\
\hline 22 & 38 & $-1.05 \%$ & -0.64 & $-27.00 \%$ & -1.59 & 64 & $-0.58 \%$ & -0.71 & $-31.59 \%^{c}$ & -3.11 \\
\hline 23 & 38 & $-3.14 \%^{\mathrm{a}}$ & -1.72 & $-30.14 \%^{\mathrm{a}}$ & -1.74 & 64 & $-2.36 \%^{\mathrm{a}}$ & -1.90 & $-33.95 \%{ }^{c}$ & -3.26 \\
\hline 24 & 38 & $-16.45 \%^{\mathrm{c}}$ & -9.37 & $-46.60 \%^{\mathrm{b}}$ & -2.63 & 64 & $-13.93 \%{ }^{c}$ & -7.50 & $-47.88 \%^{\mathrm{c}}$ & -4.50 \\
\hline 25 & 38 & $-5.13 \%^{\mathrm{a}}$ & -1.80 & $-51.73 \%^{c}$ & -2.86 & 64 & $-0.32 \%$ & -0.19 & $-48.20 \%^{\mathrm{c}}$ & -4.44 \\
\hline 26 & 38 & $-12.67 \%{ }^{\mathrm{c}}$ & -7.44 & $-64.39 \%{ }^{\mathrm{c}}$ & -3.49 & 64 & $-11.93 \%{ }^{\mathrm{c}}$ & -11.94 & $-60.14 \%^{\mathrm{c}}$ & -5.43 \\
\hline 27 & 38 & $-22.82 \%^{\mathrm{c}}$ & -11.52 & $-87.21 \%^{\mathrm{c}}$ & -4.63 & 64 & $-19.26 \%{ }^{c}$ & -14.89 & $-79.40 \%{ }^{\mathrm{c}}$ & -7.04 \\
\hline 28 & 38 & $7.28 \%^{\mathrm{c}}$ & 3.31 & $-79.92 \%^{c}$ & -4.11 & 64 & $7.66 \%{ }^{c}$ & 3.63 & $-71.74 \%^{\mathrm{c}}$ & -6.24 \\
\hline 29 & 38 & $-4.13 \% \%^{\mathrm{b}}$ & -2.14 & $-84.06 \%^{\mathrm{c}}$ & -4.25 & 64 & $-0.96 \%$ & -0.59 & $-72.70 \%^{\mathrm{c}}$ & -6.21 \\
\hline 30 & 38 & $1.51 \%$ & 1.04 & $-82.55 \%^{c}$ & -4.10 & 64 & $2.17 \%$ & 2.14 & $-70.53 \%^{c}$ & -5.88 \\
\hline 31 & 38 & $-4.02 \%{ }^{\mathrm{b}}$ & -2.45 & $-86.57 \%^{\mathrm{c}}$ & -4.23 & 64 & $-1.11 \%$ & -1.00 & $-71.64 \%^{\mathrm{c}}$ & -5.87 \\
\hline 32 & 38 & $3.04 \%$ & 0.58 & $-83.53 \%^{c}$ & -4.02 & 64 & $-0.95 \%$ & -0.95 & $-72.59 \%{ }^{\mathrm{c}}$ & -5.86 \\
\hline 33 & 38 & $-5.56 \%{ }^{\mathrm{b}}$ & -2.28 & $-89.09 \%{ }^{\mathrm{c}}$ & -4.22 & 64 & $-5.24 \%{ }^{\mathrm{c}}$ & -4.38 & $-77.83 \%{ }^{\mathrm{c}}$ & -6.18 \\
\hline 34 & 38 & $3.44 \%^{\mathrm{b}}$ & 2.01 & $-85.65 \%{ }^{\mathrm{c}}$ & -4.00 & 64 & $3.14 \%^{\mathrm{b}}$ & 2.40 & $-74.69 \%{ }^{\mathrm{c}}$ & -5.84 \\
\hline 35 & 38 & $-6.03 \%{ }^{\mathrm{b}}$ & -2.08 & $-91.68 \%{ }^{\mathrm{c}}$ & -4.22 & 64 & $-0.18 \%$ & -0.13 & $-74.87 \%^{\mathrm{c}}$ & -5.73 \\
\hline 36 & 38 & $-2.31 \%$ & -0.96 & $-93.99 \%{ }^{c}$ & -4.26 & 64 & $-2.41 \%^{\mathrm{b}}$ & -2.04 & $-77.28 \%^{\mathrm{c}}$ & -5.83 \\
\hline
\end{tabular}

Notes. ${ }^{a}$, ${ }^{b}$, and ${ }^{\mathrm{c}}$ indicate a statistical significance at $10 \%, 5 \%$, and $1 \%$ level respectively; The sample consists of 102 IPOs that occurred between January 1, 1998 and December 31, 2005: 38 Venture-Backed Companies (VB) and 64 Non-Venture-Backed Companies (NVB) make up the sample. The $A R_{t}$ and $C A R_{1, t}$ were estimated for the 36 months following the IPOs, excluding the initial return.

The values for venture-backed companies appear to be more restrained than non-venture-backed companies. However, both the sample of venture-backed companies and that of non-venture-backed companies registered 
highly negative and statistically significant values after the second year. Between the second and third years, in fact, venture-backed companies registered negative and statistically significant average cumulative abnormal returns (CAARs -81.70\%) which were higher than non-venture-backed companies (CAARs -70.97\%). Throughout the entire observation period, both registered negative, but not statistically significant, values in the order of $39 \%$.

Table 3

The Results of Cumulative Average Abnormal Returns (CAARs) in the Five Sub-periods Following the IPOs

\begin{tabular}{lllll}
\hline Event time (month) & VB & Statistical significance ( $t$-test) & NVB & Statistical significance ( $t$-test) \\
\hline CAARs $_{1,6}$ & $-11.38 \%$ & -1.32 & $-15.34 \%^{\mathrm{a}}$ & -1.89 \\
CAARs $_{1,12}$ & $-11.28 \%$ & -1.45 & $-13.65 \%$ & -1.59 \\
CAARs $_{1,24}$ & $-17.60 \%{ }^{\mathrm{a}}$ & -1.72 & $-22.54 \%^{\mathrm{a}}$ & -1.93 \\
CAARs $_{25,36}$ & $-81.70 \%{ }^{\mathrm{c}}$ & -2.52 & $-70.97 \%^{\mathrm{c}}$ & -8.17 \\
CAARs $_{1,36}$ & $-38.97 \%$ & -1.20 & $-38.49 \%$ & -1.51 \\
\hline
\end{tabular}

Notes. ${ }^{\mathrm{a}},{ }^{\mathrm{b}}$, and ${ }^{\mathrm{c}}$ indicate a statistical significance at $10 \%, 5 \%$, and $1 \%$ level respectively; The sample consists of 102 IPOs that occurred between January 1, 1998 and December 31, 2005: 38 Venture-Backed Companies (VB) and 64 Non-Venture-Backed Companies (NVB) make up the sample. The Cumulative Average Abnormal Returns (CAARs) were estimated in five sub-periods and the results were subjected to statistical significance using the $t$-test.

To summarize, the results assume values which are always negative and statistically significant for both samples of companies, even if they are more robust for non-venture-backed companies. As in the work of Ritter (1991) and Fabrizio and Samà (2001) stated that the values and statistical significance increase after the first 12 months and consistently during the period 24-36 months.

Table 4 also reveals that using the second method the values do not change much because the abnormal returns of the portfolio, with some exceptions, are always negative and for non-venture-backed companies they are almost always statistically significant.

During the whole period of analysis, the portfolio made up of venture-backed companies registered negative abnormal returns higher (BHARs -88.37\%) than those of non-venture-backed companies (BHARs -81.44\%). Also in this second analysis, the high statistical significance of the negative values is highlighted during the third year for both companies and from the second year for the non-venture-backed companies.

Table 5 shows the analysis of the sub-periods. It confirms the previous findings and strengthens the thesis of the high statistical significance of the results during the third year.

Unlike the first method, the analysis carried out with the second method shows a loss, which is on average, higher for non-venture-backed companies (BHAARs $s_{1,36}-37.81 \%$ ), even though for both samples, the values are not statistically significant.

Table 6 shows a further check carried out on the difference between the mean values registered with the use of the two methods; it was found that the difference was not statistically significant.

Table 7 shows the values of the $\mathrm{WR}_{1}$ and $\mathrm{WR}_{2}$ for the samples tested. In a six-month-period, out of 21 observed (28.57\%), the $\mathrm{WR}_{1}$ is greater than 1 , which means that the performance of the portfolio of 102 IPOs beats the "market portfolio", while in the remaining cases, the benchmark performs better than the portfolio of IPOs. 
Table 4

The Results of Buy and Hold Abnormal Returns (BHARs) for the 36 Months Following the IPOs

\begin{tabular}{|c|c|c|c|c|c|c|}
\hline \multirow{2}{*}{ Month } & \multicolumn{3}{|c|}{ IPOs VB } & \multicolumn{3}{|c|}{ IPOs NVB } \\
\hline & Sample size & BHARs $_{\mathrm{VB}}$ & $t$-test & Sample size & BHARs $_{\mathrm{NVB}}$ & $t$-test \\
\hline 1 & 38 & $-3.86 \%$ & -0.56 & 64 & $2.68 \%$ & 0.38 \\
\hline 2 & 38 & $-3.96 \%$ & -0.31 & 64 & $-8.86 \%^{\mathrm{a}}$ & -1.71 \\
\hline 3 & 38 & $-26.47 \%$ & -1.65 & 64 & $-30.76 \%^{\mathrm{c}}$ & -5.48 \\
\hline 4 & 38 & $9.83 \%$ & 0.31 & 64 & $-11.84 \%$ & -1.43 \\
\hline 5 & 38 & $5.84 \%$ & 0.20 & 64 & $-16.00 \%$ & -1.64 \\
\hline 6 & 38 & $-1.45 \%$ & -0.06 & 64 & $-9.17 \%$ & -0.94 \\
\hline 7 & 38 & $-14.61 \%$ & -0.65 & 64 & $-20.47 \%^{\mathrm{b}}$ & -2.53 \\
\hline 8 & 38 & $-8.44 \%$ & -0.40 & 64 & $-11.51 \%$ & -1.28 \\
\hline 9 & 38 & $11.72 \%$ & 0.51 & 64 & $9.77 \%$ & 0.06 \\
\hline 10 & 38 & $9.56 \%$ & 0.44 & 64 & $5.70 \%$ & 0.58 \\
\hline 11 & 38 & $-0.45 \%$ & -0.02 & 64 & $-8.21 \%$ & -0.84 \\
\hline 12 & 38 & $-10.17 \%$ & -0.62 & 64 & $-15.51 \%^{\mathrm{a}}$ & -1.79 \\
\hline 13 & 38 & $-12.50 \%$ & -0.65 & 64 & $-22.31 \%^{\mathrm{b}}$ & -2.61 \\
\hline 14 & 38 & $-3.36 \%$ & -0.15 & 64 & $-22.23 \%^{\mathrm{c}}$ & -2.94 \\
\hline 15 & 38 & $-12.57 \%$ & -0.49 & 64 & $-32.86 \%^{\mathrm{c}}$ & -4.09 \\
\hline 16 & 38 & $-13.93 \%$ & -0.61 & 64 & $-30.73 \%^{\mathrm{c}}$ & -3.57 \\
\hline 17 & 38 & $-10.11 \%$ & -0.51 & 64 & $-26.31 \%^{\mathrm{c}}$ & -3.54 \\
\hline 18 & 38 & $-12.12 \%$ & -0.62 & 64 & $-26.51 \%^{\mathrm{c}}$ & -3.19 \\
\hline 19 & 38 & $-12.49 \%$ & -0.58 & 64 & $-29.99 \%{ }^{c}$ & -3.68 \\
\hline 20 & 38 & $-5.20 \%$ & -0.24 & 64 & $-21.93 \%{ }^{\mathrm{c}}$ & -2.79 \\
\hline 21 & 38 & $-12.69 \%$ & -0.58 & 64 & $-30.61 \%^{\mathrm{c}}$ & -4.48 \\
\hline 22 & 38 & $-9.17 \%$ & -0.36 & 64 & $-30.35 \%^{c}$ & -4.41 \\
\hline 23 & 38 & $-12.44 \%$ & -0.51 & 64 & $-32.57 \%^{\mathrm{c}}$ & -4.98 \\
\hline 24 & 38 & $-33.65 \%$ & -1.47 & 64 & $-48.31 \%^{\mathrm{c}}$ & -7.60 \\
\hline 25 & 38 & $-42.73 \%^{\mathrm{b}}$ & -2.43 & 64 & $-46.29 \%^{\mathrm{c}}$ & -5.98 \\
\hline 26 & 38 & $-58.22 \%^{\mathrm{c}}$ & -3.43 & 64 & $-61.38 \%{ }^{\mathrm{c}}$ & -7.95 \\
\hline 27 & 38 & $-82.67 \%^{\mathrm{c}}$ & -4.47 & 64 & $-87.34 \%^{\mathrm{c}}$ & -11.66 \\
\hline 28 & 38 & $-68.12 \%^{\mathrm{c}}$ & -3.81 & 64 & $-73.88 \%^{\mathrm{c}}$ & -10.01 \\
\hline 29 & 38 & $-73.62 \%^{\mathrm{c}}$ & -4.02 & 64 & $-78.77 \%^{\mathrm{c}}$ & -10.59 \\
\hline 30 & 38 & $-71.00 \%{ }^{\mathrm{c}}$ & -3.80 & 64 & $-76.34 \%^{\mathrm{c}}$ & -9.91 \\
\hline 31 & 38 & $-73.70 \%{ }^{\mathrm{c}}$ & -4.48 & 64 & $-76.05 \%{ }^{\mathrm{c}}$ & -9.87 \\
\hline 32 & 38 & $-77.08 \%^{\mathrm{c}}$ & -5.45 & 64 & $-75.23 \%^{\mathrm{c}}$ & -9.39 \\
\hline 33 & 38 & $-86.15 \%^{\mathrm{c}}$ & -6.78 & 64 & $-82.21 \%^{\mathrm{c}}$ & -10.39 \\
\hline 34 & 38 & $-79.53 \%^{\mathrm{c}}$ & -5.91 & 64 & $-76.18 \%^{\mathrm{c}}$ & -9.06 \\
\hline 35 & 38 & $-86.07 \%{ }^{\mathrm{c}}$ & -6.65 & 64 & $-77.18 \%{ }^{\mathrm{c}}$ & -8.85 \\
\hline 36 & 38 & $-88.37 \%^{\mathrm{c}}$ & -6.63 & 64 & $-81.44 \%^{\mathrm{c}}$ & -9.71 \\
\hline
\end{tabular}

Notes. ${ }^{\mathrm{a}}$, ${ }^{\mathrm{b}}$, and ${ }^{\mathrm{c}}$ indicate a statistical significance at 10\%, 5\%, and 1\% level respectively; The sample consists of 102 IPOs that occurred between January 1, 1998 and December 31, 2005: 38 Venture-Backed Companies (VB) and 64 Non-Venture-Backed Companies (NVB) make up the sample. The long-run performance of a portfolio made up of $n$ IPOs is given by the measurement of the returns calculated on a time range which goes from the second day of trading to time $t$ ( $t=36$ months). The Buy and Hold Abonormal Returs were estimated.

With regard to the $\mathrm{WR}_{2}$ in 11 months out of 21 observed (52.38\%), the portfolio of IPOs $\mathrm{VB}_{\mathrm{VB}}$ outperforms the portfolio of IPOs $\mathrm{sVB}_{\mathrm{N}}$ and in 6 out of 21, this takes place after the second year, in all the other months observed, the portfolio of IPOs ${ }_{\mathrm{NVB}}$ performs better than the portfolio of venture-backed companies. In other words, the results 
obtained with the Wealth Relative generally confirm the analysis of negative abnormal returns and mainly that the performances of venture-backed companies are not so "bright" after all".

Table 5

The Results of Buy and Hold Average Abnormal Returns (BHAARs) for the Five Sub-periods Following the IPOs

\begin{tabular}{lllll}
\hline Event time (Month) & VB & Statistical significance (t-test) & NVB & Statistical significance (t-test) \\
\hline BHAARs $_{1,6}$ & $-33.45 \%$ & -0.25 & $-12.32 \%$ & -1.12 \\
BHAARs $_{1,12}$ & $-20.26 \%$ & -0.17 & $-9.51 \%$ & -0.84 \\
BHAARs $_{1,24}$ & $-76.13 \%$ & -0.72 & $-19.54 \%$ & -1.41 \\
BHAARs $_{25,36}$ & $-73.94 \%{ }^{\mathrm{c}}$ & -5.65 & $-74.36 \%{ }^{\mathrm{c}}$ & -6.90 \\
BHAARs $_{1,36}$ & $-29.72 \%$ & -0.88 & $-37.81 \%$ & -1.30 \\
\hline
\end{tabular}

Notes. ${ }^{\mathrm{a}}$, ${ }^{\mathrm{b}}$, and ${ }^{\mathrm{c}}$ indicate a statistical significance at $10 \%, 5 \%$, and $1 \%$ level respectively; The sample consists of 102 IPOs that occurred between January 1, 1998 and December 31, 2005: 38 Venture-Backed Companies (VB) and 64 Non-Venture-Backed Companies (NVB) make up the sample. The Buy and Hold Average Abnormal Returns (BHAARs) were estimated in five sub-periods and the results were subjected to statistical significance using the $t$-test.

Table 6

The Difference Between Cumulative Average Abnormal Returns (CAARs) and Buy and Hold Average Abnormal Returns (BHAARs) for Both Venture-Backed and Non-Venture-Backed companies

\begin{tabular}{lllllll}
\hline & CAARs (A) & SD & BHAARs (B) & SD & (A-B) & $t$-test \\
\hline VB & $-38.97 \%$ & 0.32 & $-29.72 \%$ & 0.33 & $-9.25 \%$ & 0.015 \\
NVB & $-38.49 \%$ & 0.25 & $-37.81 \%$ & 0.29 & $-0.68 \%$ & 0.105 \\
\hline
\end{tabular}

Notes. SD = Standard Deviation. ${ }^{\mathrm{a}}$, ${ }^{\mathrm{b}}$, and ${ }^{\mathrm{c}}$ indicate a statistical significance at $10 \%, 5 \%$ and $1 \%$ level respectively. The sample consists of 102 IPOs that occurred between January 1, 1998 and December 31, 2005: 38 Venture-Backed Companies (VB) and 64 Non-Venture-Backed Companies (NVB) make up the sample. The averages and the standard deviation of the values obtained were calculated using both methodologies (CAAR and BHAARs) for both VB companies and NVB companies in 36 months. The $t$-test measures the statistical significance of the difference between the means.

Table 7

The Results of Wealth Relative for Both Venture-Backed and Non-Venture-Backed Companies and for Both IPOs and Benchmark Portfolios

\begin{tabular}{llllllllll}
\hline Month & Sample size & $\mathrm{R}_{\mathrm{IPOs}}$ & \multicolumn{1}{c}{$\mathrm{R}_{\mathrm{b}}$} & $\mathrm{WR}_{1}$ & Sample size & $\mathrm{R}_{\mathrm{VB}}$ & Sample size & $\mathrm{R}_{\mathrm{NVB}}$ & $\mathrm{WR}_{2}$ \\
\hline 1 & 102 & $6.17 \%$ & $10.40 \%$ & 0.96 & 38 & $6.55 \%$ & 64 & $5.95 \%$ & 1.01 \\
2 & 102 & $2.99 \%$ & $6.41 \%$ & 0.97 & 38 & $5.07 \%$ & 64 & $1.76 \%$ & 1.03 \\
3 & 102 & $0.03 \%$ & $19.89 \%$ & 0.83 & 38 & $-2.49 \%$ & 64 & $1.53 \%$ & 0.96 \\
4 & 102 & $3.08 \%$ & $-11.60 \%$ & 1.17 & 38 & $8.41 \%$ & 64 & $-0.08 \%$ & 1.08 \\
5 & 102 & $-0.44 \%$ & $4.09 \%$ & 0.96 & 38 & $-0.64 \%$ & 64 & $-0.32 \%$ & 1.00 \\
6 & 102 & $-1.61 \%$ & $-5.34 \%$ & 1.04 & 38 & $-4.85 \%$ & 64 & $0.32 \%$ & 0.95 \\
$\ldots$ & $\ldots$ & $\ldots$ & $\ldots$ & $\ldots$ & $\ldots$ & $\ldots$ & $\ldots$ & $\ldots$ & $\ldots$ \\
12 & 102 & $-2.69 \%$ & $2.24 \%$ & 0.95 & 38 & $-1.13 \%$ & 64 & $-3.62 \%$ & 1.03 \\
$\ldots$ & $\ldots$ & $\ldots$ & $\ldots$ & $\ldots$ & $\ldots$ & $\ldots$ & $\ldots$ & $\ldots$ & $\ldots$ \\
18 & 102 & $-0.35 \%$ & $1.09 \%$ & 0.99 & 38 & $-0.90 \%$ & 64 & $-0.02 \%$ & 0.99 \\
$\ldots$ & $\ldots$ & $\ldots$ & $\ldots$ & $\ldots$ & $\ldots$ & $\ldots$ & $\ldots$ & $\ldots$ & $\ldots$ \\
\hline
\end{tabular}

\footnotetext{
${ }^{4}$ From a full analysis of the 36 months, it has emerged that only in $36.11 \%$ of the cases (13 months out of 36 ) the portfolio of IPOs $_{\mathrm{VB}}$ outperforms the portfolio of IPOs $\mathrm{NVB}_{\mathrm{B}}$ and this is a confirmation of the results obtained using the analysis of cumulative abnormal returns.
} 
(Table 7 continued)

\begin{tabular}{llllllllll}
\hline Month & Sample size & $\mathrm{R}_{\mathrm{IPOs}}$ & \multicolumn{1}{l}{$\mathrm{R}_{\mathrm{b}}$} & $\mathrm{WR}_{1}$ & Sample size & $\mathrm{R}_{\mathrm{VB}}$ & Sample size & $\mathrm{R}_{\mathrm{NVB}}$ & $\mathrm{WR}_{2}$ \\
\hline 24 & 102 & $-3.52 \%$ & $11.35 \%$ & 0.87 & 38 & $-5.10 \%$ & 64 & $-2.58 \%$ & 0.97 \\
25 & 102 & $-1.42 \%$ & $0.69 \%$ & 0.98 & 38 & $-4.44 \%$ & 64 & $0.37 \%$ & 0.95 \\
26 & 102 & $-1.38 \%$ & $10.82 \%$ & 0.89 & 38 & $-1.84 \%$ & 64 & $-1.11 \%$ & 0.99 \\
27 & 102 & $-4.77 \%$ & $15.81 \%$ & 0.82 & 38 & $-7.00 \%$ & 64 & $-3.45 \%$ & 0.96 \\
28 & 102 & $-1.08 \%$ & $-8.63 \%$ & 1.08 & 38 & $-1.26 \%$ & 64 & $-0.98 \%$ & 1.00 \\
29 & 102 & $1.80 \%$ & $3.98 \%$ & 0.98 & 38 & $-0.26 \%$ & 64 & $3.02 \%$ & 0.97 \\
30 & 102 & $0.41 \%$ & $-0.54 \%$ & 1.01 & 38 & $0.98 \%$ & 64 & $0.07 \%$ & 1.01 \\
31 & 102 & $-3.16 \%$ & $-0.99 \%$ & 0.98 & 38 & $-4.98 \%$ & 64 & $-2.08 \%$ & 0.97 \\
32 & 102 & $-0.19 \%$ & $-0.74 \%$ & 1.01 & 38 & $2.33 \%$ & 64 & $-1.68 \%$ & 1.04 \\
33 & 102 & $-2.59 \%$ & $2.83 \%$ & 0.95 & 38 & $-2.81 \%$ & 64 & $-2.46 \%$ & 1.00 \\
34 & 102 & $0.06 \%$ & $-3.26 \%$ & 1.03 & 38 & $0.27 \%$ & 64 & $-0.07 \%$ & 1.00 \\
35 & 102 & $-0.89 \%$ & $1.53 \%$ & 0.98 & 38 & $-4.54 \%$ & 64 & $1.27 \%$ & 0.94 \\
36 & 102 & $-0.81 \%$ & $1.61 \%$ & 0.98 & 38 & $-0.74 \%$ & 64 & $-0.85 \%$ & 1.00 \\
\hline
\end{tabular}

Notes. The sample consists of 102 IPOs that occurred between January 1, 1998 and December 31, 2005: 38 Venture-Backed Companies (VB) and 64 Non-Venture-Backed Companies (NVB) make up the sample. The returns of the sample of 102 IPOs, the benchmark and the individual sub-samples (38 Venture-Backed Companies and 64 Non-Venture-Backed Companies) were examined and the Wealth Relative $\left(\mathrm{WR}_{1}\right.$ and $\left.\mathrm{WR}_{2}\right)$ was calculated according to the Formula (12) and (13). For Example, $1.061 / 1.104=0.96$.

\section{Conclusions}

The work presented here has investigated the phenomenon of underperformance in IPOs. A sample of 102 IPOs was analyzed during the period 1998-2005 with an analysis of the aftermarket period of 36 months. The sample was made up of 64 non-venture-backed companies and 38 venture-backed companies. Similar to other studies (Ritter, 1991; Aggarwal, Leal, \& Hernandez, 1993; Keloharju, 1993; Levis, 1993; Leleux, 1993; Espenlaub, Gregory, \& Tonks, 1998; Arosio, Giudici, \& Paleari, 2001; Fabrizio \& Samà, 2001; Jaskiewicz, Gonzalez, Menendez, \& Schiereck 2005; Ritter, 2008), also in this one, the phenomenon of underperformance is confirmed for the entire period of investigation, in particular, regarding the last of the three years observed, whose values are high and statistically significant. In fact, it has emerged that both companies (venture-backed and non-venture-backed) registered negative values in the 36 months following the listing and this phenomenon would seem to be confirmed by both methodologies CARs $\mathrm{vB}_{\mathrm{VB}}(-93.99 \%)$ and BHARs $\mathrm{vB}_{\mathrm{VB}}(-88.37 \%)$ and for both samples. Venture-backed companies, unlike non-venture-backed companies, seem to be able to restrain the losses in the first 12 months (CARs ${ }_{V B}-12.38 \%$; CARs $_{N V B}-20.15 \%$; BHARs BB $_{V B}-10.17 \%$; BHARs $_{N V B}-15.51 \%$ ). During the 36 months, however, the IPOs showed negative and statistically significant values, regardless of whether the sample was composed of venture-backed or non-venture-backed companies.

The test on the difference between the average abnormal returns of the two methodologies (CAARS and BHAARs) is not statistically significant.

Finally, the Wealth Relative was calculated to measure the performance of the portfolio consisting of 102 IPOs and two sub-portfolios consisting of 38 venture-backed companies and 64 non-venture-backed companies. The results confirm that IPOs do not beat the benchmark and that the IPOs $\mathrm{VB}_{\mathrm{VB}}$ do not beat the IPOs $\mathrm{s}_{\mathrm{NVB}}$. Given the presence of institutional investors, which should reassure the market, it does not seem that the record of venture-backed companies is "brilliant". 
In conclusion, it would seem that the phenomenon of underperformance is real in our country too and this is documented by strongly negative and statistically significant values obtained from the samples of IPOs examined.

\section{References}

Aggarwal, R., Leal, R., \& Hernandez, F. (1993). The aftermarket performance of Initial Public Offerings in Latin America. Financial Management, 22(1), 42-53.

Arosio, R., Giudici, G., \& Paleari, S. (2001). The market performance of Italian IPOs in the long-run. Retrieved from http://www.papers.ssrn.com/sol3/papers.cfm?abstract_id=269834

Associazione Italiana del Private Equity e Venture Capital. (Various years). The Venture-Backed IPO market. Annual Report. Milan.

Barber, B. M., \& Lyon, J. D. (1997). Detecting long-run abnormal stock returns: The empirical power and specification of test-statistics. Journal of Financial Economics, 43(3), 341-372.

Bessler, W., \& Thies, S. (2007). The long-run performance of Initial Public Offerings in Germany. Managerial Finance, 33(6), 420-441.

Bessler, W., \& Kurth, A. (2004). The performance of venture-backed IPOs in Germany: Exit strategies, lock-up periods, and bank ownership. Retrieved from http://www.papers.ssrn.com/sol3/papers.cfm?abstract_id=497122

Brav, A. (2000). Inference in long-horizon event studies: A Bayesian approach with application to Initial Public Offerings. Journal of Finance, 55(5), 1979-2016.

Brav, A., \& Gompers, P. A. (1997). Myth or reality? The long-run underperformance of Initial Public Offerings: Evidence from venture and non-venture capital-backed companies. Journal of Finance, 52(5), 1791-1821.

Carter, R. B., Frederick, H. D., \& Singh, A. K. (1998). Underwriter reputation, initial returns, and the long-run Performance of IPO stocks. Journal of Finance, 53(1), 285-311.

Commissione Nazionale per le Società e la Borsa. (Various years). Annual report. Rome.

Drobetz, W., Kammermann, M., \& Walchli, U. (2005). Long-run performance of Initial Public Offerings: The evidence for Switzerland. Schmalenbach Business Review, 57(3), 253-275.

Espenlaub, S., Gregory, A., \& Tonks, I. (1998). Testing the robustness of long-term under-performance of UK Initial Public Offerings. Retrieved from http://www.people.exeter.ac.uk/ipt201/research/longter6_EFM2001.pdf

Fabrizio, S., \& Samà, M. (2001). Gli IPO sul mercato italiano nel periodo 1995-1998: una valutazione dell’underpricing della long-run underperformance. Quaderni di Finanza, No. 44, Commissione Nazionale per le Società e la Borsa. Retrieved from http://www.consob.it/main/consob/pubblicazioni/studi_analisi/quaderni_finanza/index.html

Fama, E. F. (1998). Market efficiency, long-term returns and behavioral finance. Journal of Financial Economics, 49(3), $283-306$.

Fama, E. F., \& French, K. R. (1996). Multifactor explanations of asset pricing anomalies. Journal of Finance, 51(1), 55-84.

Gompers, P. A., \& Lerner, J. (2003). The really long run performance of Initial Public Offerings: The pre-Nasdaq evidence. Journal of Finance, 58(4), 1355-1392.

Italian Stock Exchange. (Various years). BitStat, monthly statistics. Milan.

Jaskiewicz, P., Gonzalez, V. M., Menendez, S., \& Schiereck, D. (2005). Long run IPO performance analysis of German and Spanish family-owned businesses. Family Business Review, 18(3), 179-202.

Keloharju, M. (1993), Winner's curse, legal liability, and the long-run price performance of Initial Public Offerings in Finland. Journal of Financial Economics, 34(2), 251-277.

Kim, J., Krinsky, I., \& Lee, J. (1995). The aftermarket performance of Initial Public Offerings in Korea. Pacific-Basin Finance Journal, 3, 429-448.

Kooli, M., \& Suret, J. M. (2001). The aftermarket performance of Initial Public Offerings in Canada. CIRANO Working Papers, n. 2001s-52. Retrieved from http://www.ideas.repec.org/p/cir/cirwor/2001s-52.html

Kooli, M., L’Her, J. F., \& Suret, J. M. (2003). Do IPOs underperform in the long-run? New evidence from the Canadian stock market. CIRANO Working Papers, n.2003s-16. Retrieved from http://www.ideas.repec.org/p/cir/cirwor/2003s-16.html

Kothari, S. P., \& Warner, J. B. (1997). Measuring long-horizon security performance. Journal of Financial Economics, 43(3), 301-339.

Lee, P. J., Taylor, S. L., \& Walter, T. S. (1994). Australian IPO pricing in the short and long-run. Journal of Banking and Finance, 20(7), 1189-1210. 
Leleux, B. F. (1993). Post-IPO performance: A French appraisal. Finance, 14, 79-106.

Levis, M. (1993). The long-run performance of Initial Public Offerings: The UK experience 1980-1988. Financial Management, 22(1), 28-41.

Loughran, T., \& Ritter, J. R. (1995). The new issues puzzle. Journal of Finance, 50(1), 23-51.

Loughran, T., Ritter, J. R., \& Rydqvist, K. (1994). Initial Public Offerings: International insights. Pacific-Basin Finance Journal, 2 , 165-199.

Lyon, J. D., Barber, B., \& Tsai, Chih-Ling. (1999). Improved methods for tests of long-run abnormal stock returns. Journal of Finance, 54(1), 165-201

Mitchell, M. L., \& Stafford, E. (2000). Managerial decision and long-term stock price performance. Journal of Business, 73(3), 287-329.

Rajan, R., \& Servaes, H. (1997). Analyst following of Initial Public Offerings. Journal of Finance, 52(2), 507-529.

Ritter, J. R. (1991). The long-run performance of Initial Public Offerings. Journal of Finance, 46(1), 3-27.

Ritter, J. R. (2008). Some factoids about the 2007 IPO market. Retrieved from http://www.bear.cba.ufl.edu/ritter

Sefcik, E. S., \& Thompson, R. (1986). An approach to statistical inference in cross-sectional models with security abnormal returns as dependent variable. Journal of Accounting Research, 24(2), 316-334.

Shuster, J. A. (1996). Underpricing and crises-IPO performance in Germany (Discussion paper, 252, London School of Economics). Retrieved from http://www.2.lse.ac.uk/fmg/workingPapers/discussionPapers/fmg_pdfs/dp252.pdf 